\title{
Gérard T. Simon, a Visionary of Microscopy in Canada
}

Pierre M. Charest

Faculté des Sciences de l'Agriculture et de l'Alimentation, Université Laval, Québec, Canada

Professor Gerard T. Simon made many contributions to the development of microscopy in Canada. Born in Switzerland in 1931, Gerard T. Simon began a successful career as a professor of medicine at the University of Geneva where he created the first electron microscopy laboratory in the Department of Pathology. In 1967, he immigrated to Canada with his family where he became director of the Department of Electron Microscopy of the Banting Institute in Toronto. It is with a group of microscopists (Eric Chatfield, Frances Doane, Ivan Grinyer, Allan Howatson, Felix de la Eglisia and Harry Pullan) in this city that he founded in 1972, the Microscopical Society of Canada. Having established the Society, he proposed to the Executive committee of the MSC to have Toronto host the 9th International Congress on Electron Microscopy. The MSC then successfully organized this important meeting in 1978 that held more than 3,000 participants.

The career of Gerard T. Simon lead him to take over the electron microscopy laboratory of the Faculty of Health Sciences at McMaster University in Hamilton. His vision has made this unit one of the top microscopy core facility operated in Canada, especially for Anatomical Pathology. This core facility is still a state of the art unit in Canada where many microscopists and technicians were instructed. This accomplishment led him to become director of Anatomical Pathology at McMaster University.

In a tribute to Gérard Simon, a colleague, Dr Larry Arsenault, retired professor of McMaster University presented an example of Dr Simon's collaborative research work (1). The set of electron micrographs shown here is from a PNAS paper published in 1987, where thin sections of fixed cellular structures demonstrated cell-to-cell contact between mast cells $(\mathrm{M})$ and nerve cells $(\mathrm{N})$ of the rat small intestine suggesting cellular communication between the immune and the nervous systems (2).

In recognition of the exceptional accomplishment of Professor Simon in the Microscopy Society of Canada, a merit scientific award named after him is given annually to students in the fields of biological, physical and material sciences.

When he retired in 1996, the Honourable Jean Chrétien, Prime Minister of Canada presented him an award in recognition of his professional achievement; a wing at McMaster University has been designated after him.

In addition to being a pathologist and a microscopist, Gerard was an accomplished student of the arts, history, religions and cultures; he never missed any opportunity to lecture or to debate in these areas. Upon retirement he created a home studio where he would spent time painting. And, he and his wife, Suzanne, would entertain with fine French cuisine, fine wines and engaging discussions of science, medicine, art, history, current affairs and tennis.

\section{References:}

[1] L Arsenault, Bulletin of the Microscopical Society of Canada 41 (2013), p. 16. 
[2] RH Stead, M Tomioka, G Quinonez, GT Simon, SY Felten and J Bienenstock, Proc. Natl. Acad. Sci. 84 (1987), p. 2975.

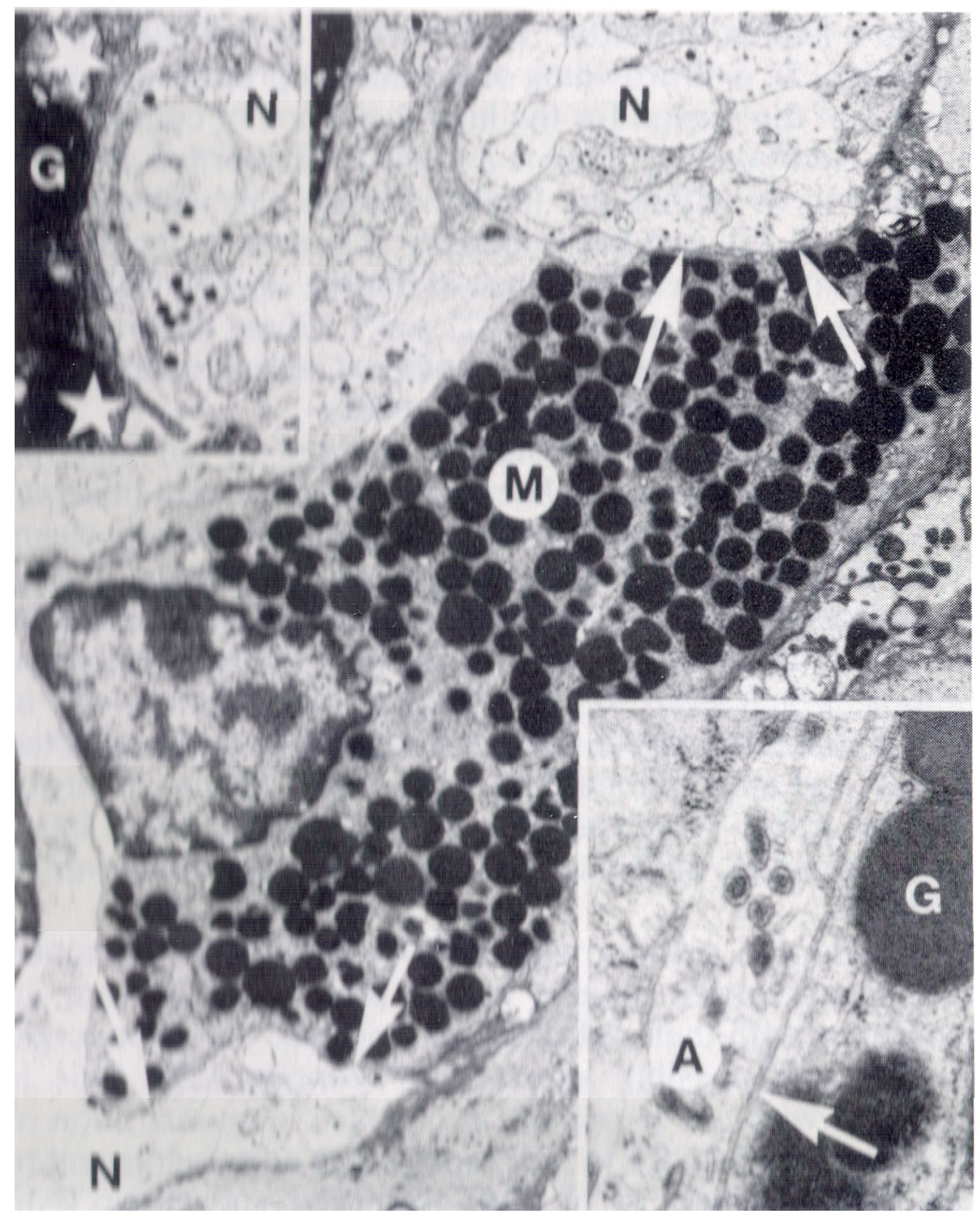

Figure 1. Cell-to-cell contact between intestinal mucosal mast cells (M) and peptidergic nerve cells $(\mathrm{N})$ in the rat small intestine. Reproduced with the permission from Stead et al. [2]. 